\title{
The Financial Collapse Of The Milwaukee Public Museum
}

David S. Krause, (E-mail: david.krause@marquette.edu), Marquette University George W. Kunter, (E-mail: george.kunter@marquette), Marquette University

\begin{abstract}
The 123-year old Milwaukee Public Museum, which had long been considered to be one of the top natural history museums in the country, found itself in dire financial straights in 2005. The museum had run large deficits for the past three years and had almost entirely eaten through its cash and long-term endowment. In June 2005 it was forced to lay off many of its experienced collections and research staff and had begun the process of preparing to sell off assets that were not a part of the "exhibit experience." Milwaukee County's Chief Executive went so far as to suggest that the Museum's celebrated 700-acre Tirimbina rain forest preserve in Costa Rica should be sold. How did this once renowned organization become a shell of its former self? What financial management and governance mistakes were made, if any, and how could this disaster have been prevented?
\end{abstract}

\section{THE MILWAUKEE PUBLIC MUSEUM CASE}

\section{Background}

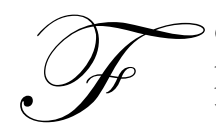

ounded in 1882, the Milwaukee Public Museum (hereafter "Museum") was among the largest and most prestigious museums of natural and human history in the country. Its style and techniques had been widely admired and copied around the world. In 1890, the Museum constructed the first total habitat diorama, setting the standard for exhibit techniques, known widely in museum circles as the "Milwaukee Style." Through its renowned exhibits, programs, and publications, the Museum has provided a valuable educational opportunity to about 1.1 million visitors each year. The Milwaukee metropolitan area has a population of 1.5 million (Beeman \& Jordan, 2004).

The Museum had been the responsibility of the City of Milwaukee from 1882 to 1976 when control was shifted to Milwaukee County (hereafter "County"). The County managed the Museum until 1992, when operation was transferred to Milwaukee Public Museum, Inc., a non-profit private corporation. All artifacts, collections, and Museum facilities were retained as the property of the County, which also provided a subsidy to the Museum.

Since its separation from the County, the Museum established several small subsidiary interests, such as Friends of the Museum and Discovery World, whose activities were included in the consolidated financial statements. By nearly every measure, prior to 2005, the transfer was determined to be a success, particularly regarding the Museum's ability to raise private funds. For instance, the County's subsidy, as measured by the percent of total revenues for the Museum, decreased from about 60\% in 1991 to less than 23\% in 2001. Private donations also had increased from $\$ 600,000$ in 1992 to about $\$ 6$ million in 2001 following a major capital fund-raising campaign. In 2002 , the Museum began signing deals to bring major traveling exhibits to Milwaukee.

In 1994, Milwaukee County issued $\$ 8.9$ million in bonds for the addition of a large screen theater (IMAX) for the Museum. In 1999, about $\$ 8$ million of the remaining outstanding debt was refunded at more favorable interest rates. In March 2000, the County, acting as a conduit for the Museum, issued an additional \$4.2 million in long-term revenue bonds to fund the new Pulicher Butterfly Wing, a two-story glass-enclosed garden designed to provide fragile 
butterflies with a year-round tropical environment. Total debt amounted to almost $\$ 16$ million following the issuance of the bonds.

The Museum's long-term chief executive officer (CEO), William Moynihan, retired in 2001. He was widely known and recognized as a skillful manager and an effective fund-raiser. His successor, Roger Bowen, served for only about one year and was acknowledged to be weaker at fundraising and relationship building than Moynihan. Terry Gaouette, the existing chief financial officer (CFO) at the time of Bowen's departure, was named the Museum's interim manager until a new CEO could be found. Action by the board of directors in April 2002 granted Gaouette the authority to sell and disburse assets from the Museum's endowment fund without the benefit of any board approval, subject to the terms of the endowment policy.

A couple of months later the Museum's board of directors also made Gaouette the acting chief operating officer (COO). When the COO job description was finalized in 2003, it required reporting to the CEO and the board of directors. In addition to his financial duties as CFO, Gaouette was responsible for Museum admissions, security, facilities, human resources, technology, and business development. Gaouette's COO position was intended to be temporary pending the recruitment and hiring of the CEO. In late 2003 the board hired Michael Stafford, an archeologist, as the new CEO. Stafford, who had less than two years of administrative experience, was strong on relationships and fund-raising, but was self-acknowledged to be weak in operational and financial skills. The board of directors then balked when Stafford wanted to take the COO duties away from Gaouette in early 2004.

\section{The Board of Directors}

The Museum's board of directors was comprised of 27 members; five appointed by the Milwaukee County Executive and four by the County Board Chairman. The remaining 18 members were elected by the Museum's current board of directors. Table 1 contains the names and professional positions of the individuals serving on the board as of May 2005. Board committees included: executive, audit and finance, development, education programming, endowment, human resources, government affairs, and nominating. There were no term limits and the board did not discipline members who showed up infrequently for meetings (Umhoefer \& Lank, 2005). Eight of the members on the board in 2005 had joined prior to 2000. In 2001, the board lost an important long-standing director, Sheldon Lubar, who resigned when he agreed to run a $\$ 25$ million fund-raising drive for the new Santiago Calatrava-designed Milwaukee Art Museum.

The board of directors usually met six times per year and approximately two-thirds of the members were present at the meetings held during the 2002 through 2004 period. Meetings ran about 90 minutes and many board members only participated by telephone. Typical board meeting agendas included a discussion of the Museum's financial status with a focus on attendance statistics and other revenue-related indicators. Board members received in advance a detailed packet outlining key items to be discussed at the meetings.

Minutes of the board meetings held from 2002 through 2004 did not disclose any particular concerns about the Museum's financial condition other than minor budget modifications. There was little discussion or concern about the use of endowment funds, increases in the line of credit, liquidation of investments, or the decline in the Museum's total net assets. When the Museum's board met in June 2003 to consider the ambitious budget for the 2004 fiscal year beginning in September, only eight members were present in the room with seven more members participating by telephone. Some late-arriving board members missed most of the budget presentation, which was the largest and most aggressive in the Museum's history. The entire budget was approved within 60 minutes without any change.

The chair of the Audit and Finance committee was the managing director of the Museum's major lender (Siegel, 2005). Another board member was the president of the Museum's second largest creditor bank. Other board members included attorneys who worked for firms who did legal work for the Museum. The County's auditors determined that since 2002, key Museum meetings violated the state's open meeting law with the board often failing to disclose why it had convened in closed session. Minutes of closed session meetings were often imprecise as to the nature of the discussions. 
Table 1. 2005 Board of Directors of the Milwaukee Public Museum.

\begin{tabular}{|c|c|}
\hline Name (Office) & Professional Position \\
\hline Richard E. Beightol & President, National Worksite Benefits (Retired) \\
\hline Kathryn Murphy Burke & Community Volunteer \\
\hline Angela Colbert & President, Production Stamping Corp. \\
\hline Sharon Cook & Director, City of Milwaukee's Intergovernmental Relations \\
\hline Michelle Crockett & V.P. Community Affairs, Genesis Behavioral Services \\
\hline Lynne De Bruim & Milwaukee County Supervisor \\
\hline Margaret A. Farrow & Former Lieutenant Governor \\
\hline Thomas L. Frenn & Attorney at Law \\
\hline Mark F. Furlong & President, Marshall \& Ilsley Bank \\
\hline Charles T. Gorham & President, Gorham, Inc. \\
\hline Charles I. Henderson & Attorney, Davis \& Kuelthau \\
\hline Kenneth A. Kerznar & Managing Director, J.P. Morgan Securities Inc. \\
\hline Dana M. Lach & Attorney, Foley \& Lardner \\
\hline Patricia Brash McKeithan & Vice President, Miller Brewing (Retired) \\
\hline David G. Meissner (Chair) & Board Member, Journal Communications Inc. \\
\hline Rose Mary Muller & Community Volunteer \\
\hline Gwen Plunkett & Community Volunteer \\
\hline Gerard A. Randall, Jr. & Executive Director, Private Industry Council \\
\hline V. Ross Read III (Vice Chair) & President \& Chairman, Clement Finance \& Leasing, Inc. \\
\hline Kip Ritchie & Community Volunteer \\
\hline $\begin{array}{l}\text { John E. Schlifske } \\
\text { Gerald Stein }\end{array}$ & $\begin{array}{l}\text { Senior Vice President, Northwestern Mutual Life } \\
\text { Chief Executive Officer, Zilber Ltd. }\end{array}$ \\
\hline Richard Weiss & Former Partner, Computer Firm \\
\hline Essie Whitelaw & Sr. Vice President, Wisconsin Physician's Service \\
\hline Edwin Wiley (Secretary/Treasurer) & Attorney/Partner, Foley \& Lardner \\
\hline Michael D. Stafford, Ph.D. & CEO, Milwaukee Public Museum \\
\hline Susan Fronk (Ex-Officio) & Friends of the Museum Board President \\
\hline
\end{tabular}

Source: Milwaukee Public Museum

\section{Financial Position}

The audited financial statements for fiscal years 2001 through 2003 are presented in Exhibits 1 and 2. The Museum changed its external accounting firm in 2004. As of July 2005, the fiscal year 2004 statements were still unaudited drafts.

Exhibit 3 contains financial information about the Museum's peer group. Two notable museums, the Field Museum in Chicago and the American Museum of Natural History in New York City, are not included because they are substantially larger than the other major U.S. natural history museums. Although they are similar in size, all of the other museums had significantly larger endowments than the Milwaukee Public Museum. Unlike the others, the Museum had a net loss in 2003 for their restaurant and retail store operations. 
Exhibit 1. Milwaukee Public Museum Income Statement as of August 31 (\$ thousands), 2004 Unaudited

\begin{tabular}{|c|c|c|c|c|}
\hline Support and Revenue & 2001 & 2002 & 2003 & 2004 \\
\hline Contributions and Membership & $\$ 3,299$ & $\$ 4,021$ & $\$ 3,704$ & $\$ 3,127$ \\
\hline Public Support & 4,300 & 4,300 & 4,407 & 3,999 \\
\hline Admissions Income & 1,197 & 924 & 1,090 & 799 \\
\hline IMAX Theater Income & 1,400 & 1,443 & 1,545 & 1,579 \\
\hline Program Income & 1,012 & 828 & 529 & 956 \\
\hline Restaurant & 2,050 & 1,910 & 1,983 & 3,022 \\
\hline Retail Store & 1,844 & 1,854 & 2,048 & 2,448 \\
\hline Net Assets Released from Restrictions & 1,076 & 1,079 & 4,955 & 4,985 \\
\hline Interest and Dividends & 523 & 607 & 72 & 355 \\
\hline Other* & 797 & 714 & 285 & 303 \\
\hline Total Revenues & $\$ 17,498$ & $\$ 17,680$ & $\$ 20,618$ & $\$ 21,573$ \\
\hline Expenses & 2001 & 2002 & 2003 & 2004 \\
\hline Curatorial & $\$ 2,005$ & $\$ 1,963$ & $\$ 1,726$ & $\$ 2,489$ \\
\hline Exhibits & 344 & 494 & 285 & 622 \\
\hline IMAX Theater & 1,381 & 1,385 & 1,586 & 1,594 \\
\hline Programs & 1,011 & 893 & 1,071 & 1,365 \\
\hline Grants & 318 & 706 & 1,079 & 3,562 \\
\hline Restaurant & 1,912 & 2,057 & 1,988 & 2,810 \\
\hline Retail Store & 2,496 & 2,182 & 2,277 & 2,652 \\
\hline Fund Raising & 1,427 & 1,119 & 1,260 & 1,281 \\
\hline Facilities & 2,635 & 2,798 & 2,666 & 3,248 \\
\hline Administration & 1,702 & 1,896 & 2,147 & 1,958 \\
\hline Depreciation & 500 & 866 & 1,043 & 1,181 \\
\hline Marketing & 566 & 511 & 461 & 468 \\
\hline Interest & 412 & 711 & 695 & 827 \\
\hline Pension & 580 & 623 & 706 & 0 \\
\hline Other** & 449 & 491 & 216 & 18 \\
\hline Total Expenses & $\$ 17,738$ & $\$ 18,695$ & $\$ 19,206$ & $\$ 24,075$ \\
\hline Revenues over expenses & $(\$ 240)$ & $(\$ 1,015)$ & $\$ 1,412$ & $(\$ 2,502)$ \\
\hline Non-operating revenue (expense) & $\$ 287$ & $(\$ 1,345)$ & $\$ 724$ & $\$ 84$ \\
\hline
\end{tabular}

Source: Milwaukee Public Museum Annual Reports

* Includes grants and contributed services. ** Includes capital reserve and contributed services. 
Exhibit 2. Milwaukee Public Museum Balance Sheet as of August 31 (\$ thousands), 2004 Unaudited.

\begin{tabular}{|l|c|c|c|c|}
\hline Assets & $\mathbf{2 0 0 1}$ & $\mathbf{2 0 0 2}$ & $\mathbf{2 0 0 3}$ & $\mathbf{2 0 0 4}$ \\
\hline Cash and Equivalents & $\$ 5,727$ & $\$ 2,636$ & $\$ 601$ & $\$ 468$ \\
\hline Investments & 4,570 & 6,133 & 5,932 & 4,319 \\
\hline Receivables & 3,900 & 3,513 & 3,139 & 2,451 \\
\hline Inventories & 576 & 899 & 871 & 756 \\
\hline Other Current Assets & 225 & 139 & 275 & 204 \\
\hline Construction in Progress & 0 & 974 & 1538 & 91 \\
\hline Furniture and Equipment & 5,255 & 6,909 & 7630 & 10,348 \\
\hline Building Additions & 18,518 & 18,672 & 19,072 & 19,160 \\
\hline Less Acc. Depreciation & $(2,841)$ & $(3,999)$ & $(4,818)$ & $(6,046)$ \\
\hline Other & 299 & 331 & 871 & 1,072 \\
\hline Total Assets & $\$ 36,229$ & $\$ 36,207$ & $\$ 35,111$ & $\$ 32,823$ \\
\hline Liabilities and Net Assets & $\mathbf{2 0 0 1}$ & $\mathbf{2 0 0 2}$ & $\mathbf{2 0 0 3}$ & $\mathbf{2 0 0 4}$ \\
\hline Payables and Accruals & 1,417 & 2,008 & 2,099 & 3,073 \\
\hline Deferred Revenue & 903 & 1,009 & 973 & 1,059 \\
\hline Lines of Credit & 710 & 1,000 & 1,500 & 2,338 \\
\hline Pension & 1,432 & 1,724 & 2,525 & 181 \\
\hline Interest Rate Swap & 0 & 475 & 407 & 364 \\
\hline Capital Leases & 0 & 0 & 180 & 424 \\
\hline Bonds & 15,700 & 15,700 & 14,600 & 14,500 \\
\hline Total Liabilities & $\$ 20,162$ & $\$ 21,916$ & $\$ 22,284$ & $\$ 21,939$ \\
\hline Net Assets & 16,067 & $\$ 3,291$ & 12,827 & 10,884 \\
\hline Total Liabilities and Net Assets & $\$ 36,229$ & $\$ 35,111$ & $\$ 32,823$ \\
\hline Source: Milwat & & & \\
\hline
\end{tabular}

Source: Milwaukee Public Museum Annual Reports 
Exhibit 3. Peer Group Analysis.

\begin{tabular}{|c|c|c|c|c|c|}
\hline & Milwaukee & Philadelphia & $\begin{array}{c}\text { Cleveland } \\
\text { Museum }\end{array}$ & $\begin{array}{l}\text { Minnesota } \\
\text { Science }\end{array}$ & $\begin{array}{l}\text { Denver } \\
\text { Science }\end{array}$ \\
\hline Income Statement & 2003 & 2003 & 2002 & 2002 & 2003 \\
\hline Total Direct Support & $\$ 3,704$ & $\$ 4,444$ & $\$ 4,681$ & $\$ 7,724$ & $\$ 11,570$ \\
\hline Government Support & 4,407 & 3,746 & - & 5,484 & 13,608 \\
\hline Admissions & 2,635 & 936 & 326 & 14,583 & 5,134 \\
\hline Special Programs & 529 & 3,369 & 962 & & 1,187 \\
\hline Net Retail Store Income & $(229)$ & 335 & 233 & 433 & 2,528 \\
\hline Net Restaurant Income & $(5)$ & 40 & - & - & - \\
\hline Investment Income & 72 & 3,359 & 7,302 & $(1,986)$ & $(97)$ \\
\hline Miscellaneous & 285 & 521 & 86 & 102 & 318 \\
\hline Total Net Revenue & $\$ 11,398$ & $\$ 16,750$ & $\$ 13,590$ & $\$ 26,340$ & $\$ 34,248$ \\
\hline Program and Exhibit Expenses & 5,844 & 11,811 & 7,647 & 28,175 & 26,854 \\
\hline Management Expenses & 2,842 & 5,002 & 1,341 & 2,021 & 5,468 \\
\hline Fundraising Expenses & 1,260 & 488 & 638 & 1,249 & 1,566 \\
\hline Total Expenses & $\$ 9,986$ & $\$ 17,301$ & $\$ 9,626$ & $\$ 31,445$ & $\$ 33,888$ \\
\hline Surplus (Deficit) & $\$ 1,412$ & $(\$ 551)$ & $\$ 3,964$ & $(\$ 5,105)$ & $\$ 360$ \\
\hline Balance Sheet & 2003 & 2003 & 2002 & 2002 & 2003 \\
\hline Cash & $\$ 601$ & $\$ 330$ & $\$ 6,024$ & $\$ 4,028$ & $\$ 9,416$ \\
\hline Total Receivables & 3,139 & 2,266 & 1,832 & 3,547 & 6,499 \\
\hline Inventories & 871 & 252 & $\$ 288$ & 172 & 309 \\
\hline Prepaid Expenses & 275 & - & - & 627 & 759 \\
\hline Total Current Assets & 4,886 & 2,848 & 8,144 & 8,374 & 16,983 \\
\hline Endowment Investments & 5,932 & 53,099 & 83,687 & 30,620 & 68,071 \\
\hline Land, Buildings, \& Equipment & 23,422 & 30,647 & 14,648 & 105,387 & 4,469 \\
\hline Other Assets & 871 & 3,496 & - & - & - \\
\hline Total Assets & $\$ 35,111$ & $\$ 90,090$ & $\$ 106,479$ & $\$ 144,381$ & $\$ 89,523$ \\
\hline Accounts Payable and Accruals & 2,099 & 846 & 498 & 2,479 & 1,861 \\
\hline Deferred Revenue & 973 & 521 & 37 & - & - \\
\hline Line of Credit & 1,500 & - & - & - & - \\
\hline Total Current Assets & 4,572 & 1,367 & 535 & 2,479 & 1,861 \\
\hline Tax-Exempt Bonds & 14,600 & 8,236 & - & - & 296 \\
\hline Other Long-Term Liabilities & 3,112 & 2,697 & - & 28,827 & 19,000 \\
\hline Total Liabilities & $\$ 22,284$ & $\$ 12,300$ & 535 & $\$ 31,306$ & $\$ 21,157$ \\
\hline Net Assets & 12,827 & 77,790 & 105,944 & 113,075 & 68,366 \\
\hline Total Liabilities and Net Assets & $\$ 35,111$ & $\$ 90,090$ & $\$ 106,479$ & $\$ 144,381$ & $\$ 89,523$ \\
\hline Financial Ratio Analysis & 2003 & 2003 & 2002 & 2002 & 2003 \\
\hline Current Ratio & 1.07 & 2.08 & 15.22 & 3.38 & 9.13 \\
\hline Quick Ratio & 0.82 & 1.90 & 14.68 & 3.06 & 8.55 \\
\hline Accounts Payable Aging (Days) & 67.0 & 17.8 & 18.9 & 28.8 & 20.0 \\
\hline Debt Ratio & $63.5 \%$ & $13.7 \%$ & $0.5 \%$ & $21.7 \%$ & $23.6 \%$ \\
\hline Fundraising Efficiency & 2.94 & 9.11 & 7.34 & 6.18 & 7.39 \\
\hline Fundraising Expense Ratio & $12.6 \%$ & $2.8 \%$ & $6.6 \%$ & $4.0 \%$ & $4.6 \%$ \\
\hline Management Expense Ratio & $28.5 \%$ & $28.9 \%$ & $13.9 \%$ & $6.4 \%$ & $16.1 \%$ \\
\hline
\end{tabular}

Source: Charity Governance.

\section{The Endowment}

The Endowment Committee consisted of five board members that met on average twice per year during the 2002 through 2004 period. Attendance at the committee meetings averaged about 70 percent. The committee was responsible for overseeing the endowment policy that called for an annual disbursement of three percent of the endowment funds for Museum operations, which could be increased to five percent if there were sufficient funds to cover current debt obligations. Unlike other organizations, the Museum's endowment funds were maintained in the 
Museum's general operating fund account (Umhoefer \& Lank, 2005). Minutes of the meetings reflected a focus on portfolio allocation, management of the funds, fees charged by the fund managers, and distribution of the income generated by the investments. Exhibit 4 shows the investment allocations for the endowment for fiscal years 2002 and 2003.

Exhibit 4. Investment Allocation 2002 and 2003 Audited Financial Statements (in millions).

\begin{tabular}{|l|c|c|}
\hline & $\mathbf{2 0 0 2}$ & $\mathbf{2 0 0 3}$ \\
\hline Common Stocks & $\$ 710$ & $\$ 767$ \\
\hline Artisan Mid Cap Fund & 628 & 761 \\
\hline Masters Select International Fund & 888 & 963 \\
\hline Vanguard 100 Index Fund & 2,265 & 2,532 \\
\hline Baird Intermediate Bond Fund & 1,643 & 909 \\
\hline Total Investment Assets & $\$ 6,133$ & $\$ 5,932$ \\
\hline
\end{tabular}

Source: Milwaukee Public Museum Annual Reports

Based on internal monthly financial statements, Gaouette first accessed the endowment assets to support the Museum's general operations in March 2004. The September 2004 minutes of the Endowment Committee included a reference to the Museum's cash flow problems, but included no mention of the use of endowment funds by management to cover any cash shortfalls. When the Museum's Endowment Committee met in January 2005, it was given information that indicated the endowment fund contained $\$ 6.4$ million at the end of calendar year 2004. That was incorrect; the endowment balance was only about $\$ 2.5$ million at the time, down from $\$ 4.3$ million at the end of August 2004. The incorrect information presented to the endowment committee was the result of a clerical error by the investment consultant to the Museum. The document shared with the committee was a December 2002 summary, not the December 2004 investment balances. The Museum's financial staff was made aware of the error ten minutes prior to the meeting by the investment consultant, but did not point out the mistake to the committee. Minutes of the January 2005 meeting also contained a discussion of the need for the Museum's board to address liquidity and working capital needs. When asked later about the withdrawal of money from the endowment, Gaouette said he expected it would be repaid from Museum earnings when attendance improved. Earnings in fiscal year 2005 did not improve, which Museum officials blamed on the local economy and freeway reconstruction in downtown Milwaukee. They also cited increased medical costs as a reason for not meeting their budget goals.

\section{The Financial Crisis}

The Board also had a 13-member Executive Committee that met on average five times per year during the 2002 through 2004 period. Attendance at the committee meetings averaged about 75 percent, with many members participating by telephone. The meeting minutes contained only sporadic discussion of the Museum's deteriorating cash position and most of the committee's time appeared to be spent on planning for future growth and expansion.

A six-member Audit and Finance Committee typically met twice each year with the first meeting devoted to reviewing and formally adopting the budget and the second meeting focusing on a review of the audited financial statements. Attendance at the committee meetings averaged about 80 percent for the three years preceding 2005 . Minutes from the meetings indicated that the external accounting firm had met with the committee each year to present the results of the annual audit. In January 2004, the committee was briefed on the 2003 financial audit, which highlighted two areas of concern. First, the external auditors noted that the Museum had experienced a total net asset loss for two consecutive years. Second, the auditors stated that "liquidity issues and cash flow management had required management's attention."

By March 2004, the banks had placed a general lien on all of the Museum's assets. Stafford, Gaouette, and the Museum board's secretary/treasurer had signed a security agreement with the banks that committed "all inventory, revenues, rents, profits, income and receipts derived in any fashion from all sources...as collateral for credit 
extended." Board and committee minutes during this period do not indicate that board members were aware of this action (Murphy, 2005).

In March 2005, Stafford announced that Gaouette would depart in April to attend graduate school. Both officers stated that a 2005 departure had been planned for several months. Prior to his departure Gaouette had been the primary Museum negotiator with Milwaukee County regarding a lease renewal that would have provided the Museum with a $\$ 70$ million subsidy over a 20 -year period (Umhoefer \& Lank, 2005). During the course of those negotiations, Gaouette had estimated the fiscal year 2004 deficit to be $\$ 448,000$, even though the Museum's bond trustee had filed financial statements with the Nationally Recognized Municipal Securities Information Repository in February 2005 that indicated a decrease in net assets of over \$2 million. In April 2005, the Milwaukee County Board approved the lease providing the subsidies to the Museum.

In early May 2005, Milwaukee County officials were notified by the museum's CEO that the local newspaper would be running a story reporting a $\$ 4.1$ million negative result for the Museum's 2004 operations (Siegel, 2005). The unanticipated news of the magnitude of the 2004 loss was of particular concern to County officials because they had been told by Gaouette to expect a deficit of about $\$ 450,000$. Although the County Board approved the new agreement and subsidy in March 2005, the final documents had not yet been executed when the Museum's financial problems were publicly acknowledged. County officials were disturbed to find that, within two months after negotiations, the Museum was in danger of not making payroll payments to its employees. County Board members demanded an audit be performed of the Museum's past and present financial condition.

In June 2005, the County's Audit Department submitted an interim report on the Museum's financial condition. The report was highly critical of the Museum's current public accounting firm, noting that "although a draft of the audited financial statements was provided to Museum, the final report had not been issued as of 283 days after the end of fiscal year." The report also criticized the Museum's accounting adjustment of over \$2 million of pension liabilities for former County employees back to County as being "without foundation." The report indicated that during a meeting in February 2005, Gaouette had stated unequivocally to County staff that the Museum's pension obligation was "fully funded." To the contrary, the County Audit Department concluded that the pension obligation was unfunded and should have appeared as a liability on the Museum's balance sheet. Although the County Audit Department did not issue a set of financial statements, their report estimated a \$5.4 million net asset loss for the fiscal year 2004. The report also estimated the net asset loss for the first quarter of fiscal year 2005 was $\$ 2.2$ million and that the total assets in the Museum's endowment fund were under $\$ 400,000$. The audit also revealed that in March 2005 an investment banking firm was hired as 'turnaround consultants' by the Museum's management at the request of its creditor banks. The investment bankers projected that, on an annualized basis, the Museum would lose over $\$ 7$ million from normal operations in fiscal year 2005.

The county audit spread the blame widely for the Museum's dire financial straits and stated that the failure of the institution to tell county officials about its problems before a vote on a new subsidy agreement in March 2005 was a "violation of the public trust." The audit indicated that financial problems were known to Museum managers for at least a year before the March 2005 vote by the County Board on a new partnership deal (Here, 2005). The audit also claimed that Museum officials were reassuring the county about its financial situation in the run-up to the vote even while they were negotiating with their bankers and working on a plan to slash expenses and staff. Two days after the audit was released in June 2005, Stafford announced his resignation and two weeks later the board chairman resigned his position. Following the resignations, County Executive Scott Walker called for a criminal probe of the Museum's debacle by the State of Wisconsin's Attorney General.

David Messiner, the Museum board's chairman attributed the unexpected size of the deficit "to overly ambitious budgeting, fund-raising shortfalls and the county's refusal to administer pension benefits for some excounty employees." He also noted that the final audit of the Museum's 2004 fiscal-year financial statements had not been completed in a timely manner. Stafford commented that Museum "grew too fast, too quickly, and it grew beyond its means of support." In June 2005 the Museum laid off 56 of its 240 staff members to partially contain the deficit. 
In June 2005, a new five-person oversight board, which contained no existing directors or officers, was created by Milwaukee County officials to direct the Museum. This occurred as a result of the county and the lenders reaching an agreement that provided the Museum with $\$ 6$ million of new guaranteed debt. The agreement reached with the lenders by Milwaukee County called for a reduction in the Museum's annual operating budget from $\$ 22$ million to $\$ 13$ million. By the beginning of July 2005, the Museum had laid off many of its experienced collections and research staff and had begun the process of preparing to sell off assets that were not a part of the "exhibit experience." Milwaukee County Executive Walker suggested that the museum's celebrated 700-acre Tirimbina rain forest preserve in Costa Rica be among the assets sold.

How did this once renowned organization become a shell of its former self? What financial management and governance mistakes were made, if any, and how could this crisis have been prevented? What can be done to restore the Museum to its former self? These are the questions that the Museum's new oversight board faced when they met for the first time in July 2005.

\section{REFERENCES}

1. Beeman, P., \& Jordan, E. (2004, September 19). Iowa's newest attraction would be one-of-a-kind, but comparisons to other projects raise attendance questions, Des Moines Register, Retrieved June 28, 2005, from http://www.dmregister.com/apps/pbcs.dll/article? AID=/20040919/BUSINESS04/409190370/1029.

2. Here, J. J. (2005, June). An audit of Milwaukee Public Museum, Inc. 2005 financial crisis (Interim Report of the Milwaukee County Department of Audit). Milwaukee, WI.

3. Milwaukee Public Museum (1999-2004). Annual Reports.

4. Murphy, B. (2005, May 23). Public museum disaster: How did this happen? Milwaukee Magazine, Retrieved June 24, 2005 from http://www.milwaukeemagazine.com/ murphyslaw/ 2005-05-23.html.

5. Siegel, J. (2005, May 20). Milwaukee Public Museum: The numbers are in, Charity Governance, Retrieved June 28, 2005 from http://charitygovernance.blogs.com/charity_governance/ 2005/05/ part_2the_milwa.html.

6. Siegel, J. (2005, May 26). Milwaukee Public Museum: The other shoe has dropped - the endowment was stripped, Charity Governance, Retrieved June 28, 2005 from http:// charitygovernance.blogs.com/charity_governance/2005/05/milwaukee_publi_4.html.

7. Umhoefer, D., \& Lank, A. D. (2005, June 6). Museum panel given bad endowment numbers:

8. Misstatement in January was off by nearly \$4 million, Milwaukee Journal-Sentinel, Retrieved June 27, 2005 from http://www.jsonline.com/news/metro/jun05/333501.asp.

9. Umhoefer, D., \& Lank, A. D. (2005, June 13). Museum gets loan bailout: County would guarantee $\$ 6$ million to \$9 million, Milwaukee Journal-Sentinel, Retrieved June 21, 2005 from http://www.jsonline.com/news/metro/jun05/333501.asp.

10. Umhoefer, D., \& Lank, A. D. (2005, June 26). Hands-off board hurt museum, Milwaukee Journal-Sentinel, Retrieved June 27, 2005 from http://www.jsonline.com/news/metro/jun05/ 336605.asp. 


\section{Teaching Notes: The Financial Collapse Of The Milwaukee Public Museum}

\section{CASE DESCRIPTION}

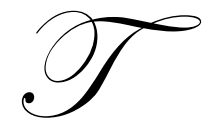

his case is about the Milwaukee Public Museum, Inc., a non-profit private corporation. Founded in 1882, the Milwaukee Public Museum became a private non-profit corporation in 1992. The case focuses on events which occurred during the period 2003-2005 when the Museum experienced severe financial difficulties. The case involves the financial problems experienced by the Museum during this period. These financial problems raised a number of important issues. These include the following: (1) the use of endowment funds and the monitoring and control of these funds; (2) the relationship between the museum management and the Board of Directors; (3) the appropriate organizational structure in such a setting; (4) individual interactions and abilities of the people involved; (5) oversight responsibilities and due diligence of the Board of Directors; and (6) implications of the problems for people who depend upon the Museum, including employees and the community at large.

This case can be used to discuss a variety of financial issues related to both for-profit and non-profit organizations. These include institutional and legal issues related to the management and use of endowment funds, corporate governance issues related to the role of the board in financial matters, ethical and legal issues related to financial disclosure, the financial management of a museum with separate operational entities, and operational management of a museum.

This case would be appropriate for both undergraduate seniors with an interest in finance, as well as MBA students with an interest in finance and/or non-profit organizations. The case does not require an extensive background in finance, but rather a familiarity with some basic financial techniques and accounting terminology. Some familiarity with income statements and balance sheets is also required. It would also be preferable but not necessary that students have some prior exposure to investments.

The case can be adequately discussed in a 1 to 1-1/2 hour classroom period. This could be extended if more of the many related issues are discussed. Perhaps the instructor may want to provide some general introduction to non-profits and the use and role of endowment funds. One may want to discuss some of the interpersonal and/or organizational structure issues which the case addresses. Students will probably need to spend 3 to 5 hours preparing the case. This would involve reading the case, identifying and thinking about many of the important issues raised, doing some financial analysis and providing some kind of solution to the case. If a written report is required these may increase the preparation time by 50 percent.

\section{CASE SYNOPSIS}

This case is about severe fiscal problems which occurred during the period 2003 to 2005 at the highly respected Milwaukee Public Museum, a non-profit corporation which receives an annual subsidy from Milwaukee County. It is presented in a manner that allows the students to see how quickly bad things can happen to good organizations. Although this case focuses primarily on the financial difficulties at the Museum, it does raise an extremely wide variety of other issues which can be discussed. These include issues such as corporate governance, ethics, disclosure, organizational structure, interpersonal interactions, the use of endowment funds, the role and responsibilities of Board members, and the impact on the public at large. It also allows the instructor to expose students to the operational difficulties of non-profits and recognize that even these organizations can have dire operational and financial problems. Another attractive feature of the case is that it does not require a high degree of financial sophistication, but rather much more critical thinking and analysis. It does require one to be familiar with 
financial statements and basic accounting terminology. Finally, the fact that this is a one of the largest most prestigious museums in the country with a long and distinguished history allows students to identify and sympathize with the situation almost immediately. The case should be of interest to a wide variety of business students.

\section{SUGGESTIONS AND CASE QUESTIONS}

This case can be presented in class in order to introduce students to a number of issues which have already been mentioned above. Not all of these issues can be discussed at length in a normal one hour class. Consequently, discussion of the case can be done effectively in a number of different formats. In a broad sense this case raises two areas for discussion: governance, along with the related agency issues, and operational and financial problems for a non-profit museum. One format would be to discuss both areas extensively in one 2-hour class or two 1-hour classes. Another format would be to discuss one of the areas extensively in a 1-hour class. A third format would be to discuss both issues simultaneously but in less detail in a 1-hour class.

\section{Notes: Governance and Related Agency Issues}

In this case the problems experienced by the Museum can be traced to a variety of agency problems and governance issues. As a non-profit corporation, the Museum had no shareholders, yet Milwaukee County guaranteed the revenue bond issues used to fund the museum. Because of fiscal constraints during the recession of 2001-02, the County did not monitor the Museum's operations or audit the books on an on-going basis. As a consequence, there was no oversight coming from sources which appear naturally in most corporations. Because the debt was guaranteed by the County, the bondholders did not concern themselves with the financial condition of the Museum. This lack of external oversight put an additional emphasis on the role and responsibilities of the Board of Directors which oversaw the Museum. However, Board member activity appears to have been operating at the low end of the spectrum. Board attendance was low and much of the meeting participation was conducted via the telephone. In addition, two of the Board's most influential members were high level officers in the Museum's creditor banks.

There were a number of other contributing circumstances to the financial crisis that appeared because of poor Board decisions. First, the new CEO, Stafford, an archaeologist by experience and training, was a self-acknowledged business and financial neophyte. Consequently, the Board could not depend upon the most important person in the Museum for sound and reliable business and financial information and judgment. To offset Stafford's managerial deficiencies, the Board created a structure that had the CFO reporting directly to both the CEO and the Board. Thus, the relationship between the Board, CEO, and CFO was highly unusual and no doubt resulted in mixed messages regarding the Museum's financial condition. To further complicate matters, the $\mathrm{CFO}$ also served as the $\mathrm{COO}$, despite the CEO recommendation to separate the two positions. This may have led to a conflict of interests and additional pressures on the relationship between the CEO and CFO. Also, with one person serving as the both CFO and COO there was no effective "checks and balances" built into the system.

The above matters may be related to additional problems. The Museum changed external accounting firms in 2004 and the new firm had not provided audited financial statements in a timely manner. Un-audited statements existed within five months of the fiscal year end, but final statements had not been issued as the oversight board began its during in July 2005 - 10 months after the end of the fiscal year. In addition, the outside investment consulting firm provided the wrong financial statements regarding the Museum's endowment fund. Instead of the Endowment Committee reviewing the December 2004 ending investment balances, they were accidentally given two year old statements. Interestingly, about 10 minutes before the Endowment Committee met to review the statement, the CFO was notified of mix-up and decided to present the outdated numbers without informing the committee members. Given the dramatic increase in the investment balance from August 2004 to December 2004, members of the committee should have caught the error. In any event, the failure of the investment consulting firm and the CFO to inform the members of the Endowment Committee of the error is inexcusable. If the correct figures were presented at the meeting it is likely that members would have seen that the fund balances had dropped by several million dollars. Questions by committee members would have hopefully brought to light that the CFO was funding the Museum's mounting operating losses with withdraws from the investment fund - an action that was in direct violation of the endowment policy that only allowed for a five percent annual draw. 
Interestingly, in March 2004 the bank lenders put a general lien on the Museum's assets because of loan covenant violations related to a weakening liquidity position. It does not appear that the Board or Milwaukee County was informed of this action - despite the signatures required by the CEO, CFO, and Board secretary/treasurer. This raises issues about who knew and when they knew. It is hard to imagine the officers of the two largest credit banks, who also were on the Museum's Board, did not know about general lien on assets and the deteriorating financial condition. Another curious issue related to the lien placed on the assets is that the Museum itself actually had few unencumbered assets since most of the major assets (which included the exhibits, collections, and facilities) were owned by the County. The assets the Museum possessed - which included the IMAX theater and butterfly wing were tied to the County via the revenue bond issued to fund the expansions.

In summary, the major problem was the absence of any significant, detailed oversight by the Board of Directors which was further compounded by the Museum's convoluted structure of management responsibilities. Placing responsibility for administration, operations and finance in one person was problematic given the CFO/COO's ability to authorize the sale and disbursement of endowment fund assets - and the CEO appeared to have no interest or clue as to what was happening financially. It is alarming that the $\mathrm{CFO} / \mathrm{COO}$ first accessed the endowment to support the Museum's weakening financial condition in March 2004, yet no Board members were aware of this activity until over one year later - by which time the endowment fund had been virtually depleted. The County's audit revealed a trail of clues which should have been detected by the Board long before the Museum's financial crisis became public.

\section{Notes: Museum Financial and Operating Condition}

Yearly Museum financial statements are provided from 2001 through 2004. While non-profit financial statements are generally more difficult for students to understand, the basic trends in the Museum's deteriorating condition are evident with simple financial ratio analysis. Examination of the Museum's balance sheet shows a high and growing level of indebtedness with very few liquid assets other than the endowment fund which was in decline. In addition, the Museum had a significant amount of short-term term with an insufficient amount of current assets to cover this debt. The declining current and quick ratio, the huge accounts payable days, and the high (and increasing) debt ratio should have been obvious signals of a pending financial crisis.

Financial Ratio Analysis

\begin{tabular}{|l|c|c|c|c|}
\hline & $\mathbf{2 0 0 1}$ & $\mathbf{2 0 0 2}$ & $\mathbf{2 0 0 3}$ & $\mathbf{2 0 0 4}$ \\
\hline Current Ratio & 3.4 & 1.8 & 1.1 & 0.6 \\
\hline Quick Ratio & 3.3 & 1.6 & 0.9 & 0.5 \\
\hline Accounts Payable Aging (Days) & 47.2 & 66.9 & 70.0 & 102.4 \\
\hline Debt Ratio & $55.7 \%$ & $60.5 \%$ & $63.5 \%$ & $66.8 \%$ \\
\hline
\end{tabular}

Department Revenue Analysis (\$ in thousands)

\begin{tabular}{|c|c|c|c|c|}
\hline & 2001 & 2002 & 2003 & 2004 \\
\hline IMAX Theater Revenue & $\$ 1,400$ & $\$ 1,443$ & $\$ 1,545$ & $\$ 1,579$ \\
\hline IMAX Theater Expense & $(1,381)$ & $(1,385)$ & $(1,586)$ & $(1,594)$ \\
\hline IMAX Theater Net Profit & $\$ 19$ & $\$ 58$ & $(\$ 41)$ & $(\$ 15)$ \\
\hline Restaurant Revenue & $\$ 2,050$ & $\$ 1,910$ & $\$ 1,983$ & $\$ 3,022$ \\
\hline Restaurant Expense & $(1,912)$ & $(2,057)$ & $(1,988)$ & $(2,810)$ \\
\hline Restaurant Net Profit & $\$ 138$ & $(\$ 147)$ & $(\$ 5)$ & $\$ 212$ \\
\hline Retail Store Revenue & $\$ 1,844$ & $\$ 1,854$ & $\$ 2,048$ & $\$ 2,448$ \\
\hline Retail Store Expenses & $(2,496)$ & $(2,182)$ & $(2,277)$ & $(2,652)$ \\
\hline Retail Store Net Profit & $(\$ 652)$ & $(\$ 328)$ & $(\$ 229)$ & $(\$ 204)$ \\
\hline
\end{tabular}


An examination of the income statements reveals increasing revenues for the IMAX theatre, restaurant, and gift shop departments; however, these usual "profit centers" generally were not producing positive results. The cumulative loss of the retail store was significant and an indication of an inefficient operation. Even the IMAX theater, usually a museum "cash cow," produced a net loss in 2003 and 2004.

Further examination of the income statement reveals revenues for memberships, admissions, and County support declining during the four year period. Although total revenues rose, these were subsided by heavy withdrawals from the endowment fund, especially in 2004. On the expense side, most operating expenses grew modestly. The Museum's Fundraising Efficiency Ratio (Contributions and Membership Revenue divided by Fundraising Expenses) was slightly lower than average and declining in 2004. According to Indiana University's Center on Nonprofits and Philanthropy, the average Fundraising Efficiency Ratio is 3.00.

\begin{tabular}{|l|c|c|c|c|}
\hline & $\mathbf{2 0 0 1}$ & $\mathbf{2 0 0 2}$ & $\mathbf{2 0 0 3}$ & $\mathbf{2 0 0 4}$ \\
\hline Fundraising Efficiency & 2.31 & 3.59 & 2.94 & 2.44 \\
\hline
\end{tabular}

In 2004, a dramatic increase in grant expenditures was realized and at the same time pension liabilities of the Museum were removed arbitrarily and unilaterally by the CFO. The unaudited financial statements indicated a $\$ 2.5$ million loss in 2004, which was actually understated due to the endowment withdrawals and change in pension expenses. By the later portion of calendar year 2004, almost $\$ 500,000$ per month was being withdrawn from the endowment to cover operating shortfalls. The Museum's endowment balance was about $\$ 6$ million in 2003, but by April 2005 the endowment was estimated by the County to be only $\$ 350,000$. The endowment had been essentially drained, despite a policy which limited withdrawals to only 5 percent per year.

The Peer Group Museum financial data was provided in the case for fiscal year 2003. The Milwaukee Museum's debt ratio was more than 3 times larger than any of its peers and the current and quick ratios were far below the peer averages. The peer group comparison also showed that management and fundraising expenses were significantly higher which helped contribute to the heavy losses. On the other hand, the peer group comparisons on the revenue side do not suffer such a disparity. As discussed above, the Museum's losses in its departmental operations (i.e. restaurants, retail shop, and IMAX theatre) were quite disturbing - especially compared to the peer group. Looking at the peer group balance sheet comparisons, one can see the Museum's large amount of debt (discussed above) and the very low level of long-term endowment relative to the others. The Museum's endowment fund was approximately one-tenth of it's peers.

In summary, it appears that the source of the Museum's financial difficulties was two-fold. First, Museum expenses were too high relative to its peers; especially for its departmental operations. Secondly, the Museum's endowment fund was inadequate to support the growth that was taking place in the Museum's operations. While Museum staff cuts took place almost immediately in June 2005, it remains to be seen whether adequate external contributions will be forthcoming to adequately support the Museum operations. The financial situation at the time of the case was extremely dire and the Museum's future was uncertain. The Museum's new five-member oversight board faced a substantial challenge when they met for the first time in July 2005 to work on a plan to save the institution.

\section{Questions for Classroom Discussion}

The following are questions about the case which can be used for discussion in a classroom setting or assigned to students as written work or presentation in class:

1. What were the strengths and weaknesses of the Museum's new CEO and how did this CEO differ from previous leaders? Did the CEO's lack of financial and operational sophistication set the stage for the problems which arose? 
2. What were the reasons for having the odd organizational structure, for example one person as both CFO and $\mathrm{COO}$ simultaneously? How did this organizational structure contribute to the Museum's problem which evolved?

3. What was the role of the endowment for the Museum? What are the usual constraints and requirements regarding the operations of an endowment? How could the CFO/COO spend the entire endowment without the Board's knowledge?

4. What is the role of the Board of Directors for the Museum? What was composition of the Board in terms of member attributes? Should the Board have been aware of and taken action earlier than it did? Were there any signals of information which should have alerted members to the problems which were developing?

5. Describe and discuss the situation which led to the wrong information being presented at the end-of-the-year 2004 Endowment Committee meeting. Should the Board members have recognized that the wrong information may have been given to them? What are possible ethical principles or professional practices which may have been violated by the $\mathrm{CFO} / \mathrm{COO}$ and the investment consulting firm?

6. Are there any ethical principles or professional practices that were violated by the $\mathrm{CFO} / \mathrm{COO}$ during his tenure at the Museum?

7. What people or groups of people have been affected by the events which occurred at the Museum during the period 2003 to 2005? How were these people impacted specifically?

8. How could have the problems been avoided at the Museum? What steps and actions should have been taken sooner to avoid the Museum's financial problems?

9. Did the individual personalities of the Board members, $\mathrm{CFO} / \mathrm{COO}$, and $\mathrm{CEO}$ perhaps contribute to the Museum problems and the inability to solve the problems in a timely fashion?

10. Were there potential ethical and professional practice violations made by the Museum auditing firm? Should the Museum Board have recognized the auditing firm actions as a signal that problems may exist?

\section{Useful Websites}

1. Milwaukee Public Museum: www.mpm.edu

2. Charity Governance: www.charitygovernance.com

3. Milwaukee Journal-Sentinel: www.jsonline.com

4. Urban Institute: www.urban.org/

5. Natural History Museums and Collections: www.lib.washington.edu/sla/natmus.html

6. Yahoo! Natural History Museum Directory: http://dir.yahoo.com/Society_and_Culture/Environment_and_Nature/Natural_History_Museums/ 